\title{
The Invention of Typicality: Parmigiano-Reggiano Cheese Between Tradition and Industry
}

\author{
Stefano Magagnoli \\ University of Parma, Parma, Italy
}

\begin{abstract}
Parmigiano-Reggiano cheese is one of the best known and most widely imitated typical products in the world. It is a cheese that enjoys an excellent reputation, deeply rooted in history. As far back as the 14th century, it was mentioned by poets and writers as a symbol of opulence and good living. Travellers took note of Parma Grana cheeses in their Italian diaries in 16th-17th centuries and it also appeared in the cookbooks of the Renaissance. In those years, however, Parmigiano-Reggiano cheese was an expensive luxury product that needed guarantees of its origin and controls that ensured the highest quality. A turning point occurred in the last decades of 19th century, when the demand of Parmigiano cheese saw a big increase as a result of the expansion of markets. The Parmigiano brand was known worldwide, so producers were able to exploit the reputation of the product and the fame of Parma and the surrounding area as a marketing tool. The beginning of a true communication strategy for the product took place in the early 1960s, in parallel with the expansion of markets in the economic boom and taking advantage of the most important "new media" of that period: the television.
\end{abstract}

Keywords: Parmigiano-Reggiano cheese, consortium of Parmigiano-Reggiano, typicality, terroir, reputation of goods, the invention of tradition

\section{Making the Reputation}

Parmigiano-Reggiano cheese is one of the best known and most widely imitated typical products in the world. It is a cheese that enjoys an excellent reputation, deeply rooted in history. As far back as the 14th century, it was mentioned by poets and writers as a symbol of opulence and good living (Boccaccio, 1527). Travellers took note of Parma Grana cheeses in their Italian diaries in 16th-17th centuries and it also appeared in the cookbooks of the Renaissance (Maestro Martino de Rossi, 1467; Tanara, 1674). In those years, however, Parmigiano-Reggiano cheese was an expensive luxury product. It needed guarantees of its origin and controls that ensured the highest quality (guarantees about the origin the quality of products are peculiar to every luxury good-food and non-food ones), constantly exposed to attempts of imitation and counterfeiting (Magagnoli, 2013); the ancien regime guild system was for many centuries an effective response to such risks (Guenzi, Massa, \& Moioli, 1998). It is talking about a period in which traders were involved in a system (a game) of mutual guarantees. It was obviously a game that had costs, which could however be easily shifted onto the end consumers who were fairly or even completely insensitive to price.

This paper reflects these topics and particularly the marketing tools used by the consortium of

Stefano Magagnoli, Ph.D., associate professor, Department of Economics, University of Parma, Parma, Italy.

Correspondence concerning this article should be addressed to Stefano Magagnoli, Università di Parma, Dipartimento di Economia, via J.F. Kennedy 6, 43125 Parma, Italy. 
Parmigiano-Reggiano after WWII to convince consumers to eat Parmesan cheese, already became an industrial good. The challenge in this period was strong: The Parmesan cheese was mainly consumed in the North of Italy and the first goal of the market strategy was to "export" Parmigiano in the regions of the Centre and the South of Italy where other cheeses are generally consumed. The communication path was particular and it unrolled between the search of "modernity" and the recovery of "tradition".

The paper, studying the advertisings, analyses how Parmigiano-Reggiano had conquered the markets and faced the competition of other Grana cheeses. The topic, obviously, is very important for food studies, taking into account that Parmigiano-Reggiano is one of the typical products more known world-wide.

\section{Entering the Industrial Age}

Parmigiano-Reggiano cheese "built" its international reputation, as a high quality cheese, in the pre-industrial age, a period characterized by two main factors: The demand was not price sensitive, because consumers were luxury good consumers; and the product was (such as it is today) made with artisan techniques which resisted standardization. A first change in the exploitation of the relation between food and its place (as well as in the perception of reputation by the consumers) (Magagnoli, 2015a) of origin occurred in the 18th century, during the "industrious revolution" that, broadening the offer of traded goods, allows multi-faceted choices in consumption, influenced by ongoing fashions (De Vries, 1994; Smart Martin, 1993). Some food products, identified by their region of production (the case of Madeira wine is the most renown), acquire in the consumers mind the function of social markers (Hancock, 2009).

A true turning point occurred in the last decades of 19th century, with the emergence of the modern food processing industry and the "first wave of globalization" (Bordo, Taylor, \& Williamson, 2003). It was in those years that the demand for products like Parmigiano-Reggiano cheese saw a big increase as a result of the expansion of markets and developments in transport (Levati, 2002). The Parmigiano brand was known worldwide, so producers were able to exploit the reputation of the product and the fame of Parma and the surrounding area as a marketing tool. The producers who exported directly tried to enhance their brand without distancing themselves too much from the "collective" image of a product coinciding with a place. The middlemen (who collected and sold wheels of cheese from hundreds of micro-units) were interested in eliminating individual brands in order to sell a product as homogeneous as possible, at a price that was easier to control. These two trends also converged towards the most profitable solution for those producers in a position to export directly. By giving up their own brand, they found it easier to sell their product and, above all, became part of a much more controlled market.

Nevertheless, in the last decades of 20th century, the link between product and place of production partially broke down. Many years previously producers in Lombardy had temporary become stronger than producers in Emilia, which is the area of Parma. For a time, producers in Lombardy were able to avail themselves of more productive techniques of processing. For this reason, Parmigiano cheeses with the best quality were those produced in Lombardy, as is highlighted at the end of the century Universal Exhibitions, where the prize-winning Grana cheeses were not from Emilia-Romagna (Magagnoli, 2015b).

How and with which tools does the Parmigiano-Reggiano cheese overlap anew its "typicality" and its place of origin? How is it possible to communicate to consumers the alleged typicality of a cheese that in the 20th century is made with industrial techniques? In the following pages, the making of collective action carried on by the consortium will be examined. Then the paper will analyse the advertisings to answer to the previous questions. 


\section{Building the Collective Action}

Only between 19th and 20th centuries did the productive system in Emilia find anew the capacity to make high quality Grana cheeses. They started to follow more modern standards of hygiene. Using starter-whey for example makes it possible to reduce the percentage of cheeses damaged by ripening. They also started to standardize the taste of the product. All this was obviously made possible by a sort of "industrialization" of Parmigiano manufacturing. This process was related not so much to the organisation of production, as hundreds of small dairies remained on the market. It concerned more manufacturing techniques (Zannoni, 1999).

These changes took place against the background of activities to create the consortium, which was set up in the 1930s, and to define clearly the production area. This was in the end the result of a long political mediation which started at the beginning of the century.

In 1901, in fact, it was the Chamber of Commerce of Reggio Emilia which proposed the setting up of a trade union for cheese producers and traders to provide a guarantee of authenticity of products destined for export. An additional step towards the birth of the consortium was taken in 1909, when, in an attempt to find a solution to the problem of protecting the origin, representatives from the Chambers of Commerce of Parma, Reggio, Modena, and Mantua met to define a hypothetical branding of the grana-type cheese produced in these four provinces, but the problem found no final solution. Between 1920 and 1921, the relaunch of the dairy sector became a "must" for administrative institutions and for the economic organizations. As a result, a first permanent interregional committee was established in September 1921 to support the dairy sector with its seat at the Chamber of Commerce of Reggio Emilia.

In 1926 this "Interprovincial Consortium" in collaboration with some French producers promoted, during the 7th Milk Processing International Conference, a proposal to define the "names of types of cheese deriving from their region of origin" in order to prevent fraud to the detriment of buyers. The "denomination model" adopted was essentially copied from the AOC (Appellations d'Origine Contrôlées) system for wines, which had been under development in France since the first years of the century. In 1928, the time was ripe also in Italy. Therefore, upon request of the "Association of Entrepreneurs" and of the "Provincial Council of Corporate Economy" (i.e., the Chamber of Commerce) of Reggio-Emilia, the "Voluntary Consortium for the Protection of Grana Reggiano" was founded. The operation which led to the consortium was basically a commercial initiative, even though purely productive issues were also involved. Indeed, the consortium had to guarantee that the cheese produced by its members had minimum requirements (maturation, fat percentage, origin of the raw material, etc.), but the main activities were aimed at promoting the product in the domestic and foreign markets.

This time the operation was immediately welcomed by almost all the producers from Reggio Emilia. Considering the success and undoubted advantages that the consortium granted producers from Reggio, after several meetings and after accepting the membership of producers from the neighbouring provinces, the Consorzio Volontario Interprovinciale (Interprovincial Voluntary Consortium) was set up in 1934, with the inclusion of producers from Parma, Modena, and Mantua. Finally, in 1937, the production area was enlarged to include the province of Bologna to the west of the river Reno. Only the following year, "protected denomination" of the cheese produced in the area covered by the consortium was established with a decree as: "Grana Parmigiano-Reggiano", a denomination which continues to be used today. 
The new consortium and the defined production area made it possible to make the links with terroir clearer. These links made it possible for marketing strategies to use the idea of a cheese "made in history" (on the use of the term "terroir" and about the link with the product marketing see the papers collected in works of Ceccarelli, Grandi, and Magagnoli (2013). Once the product was made and the production system in place, it was necessary to construct the typicality.

\section{Communicating the Typicality}

In the first decades of the 20th century, significant investments were made in posters, such as those by Achille Luciano Mauzan for the Bertozzi company (Figure 1) and by Gino Boccasile for the Tavella company (Figure 2). The posters made for the Pelagatti firm were particularly interesting (Figures 3-4). Pelagatti was a pioneer in modern marketing and its communication strategy was based on the equivalence of Parmigiano and luxury.

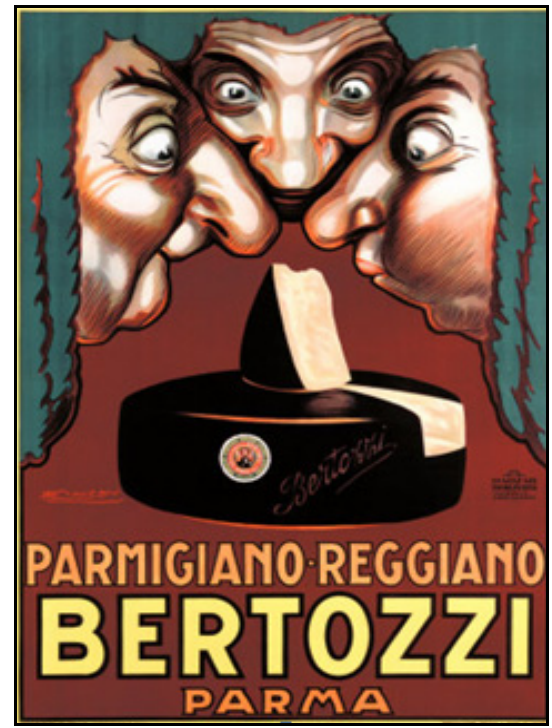

Figure 1. Advertisement poster, Parmigiano-Reggiano Bertozzi (1930).

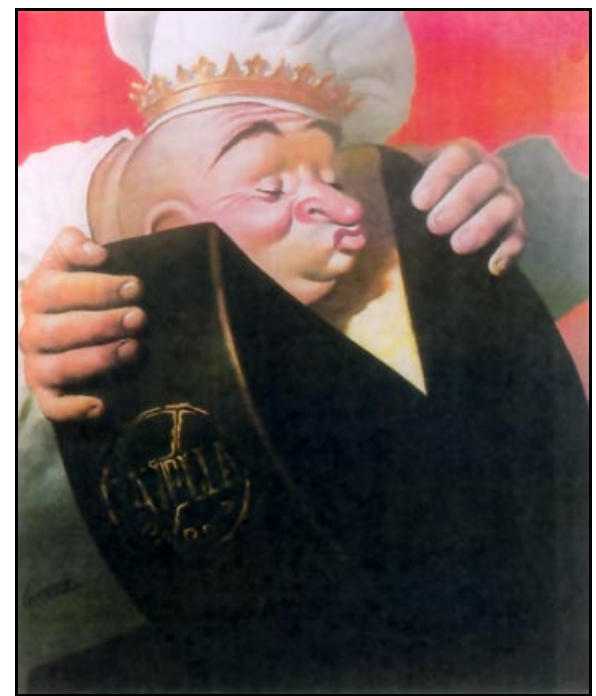

Figure 2. Advertisement poster, Parmigiano-Reggiano Tavella (1940). 


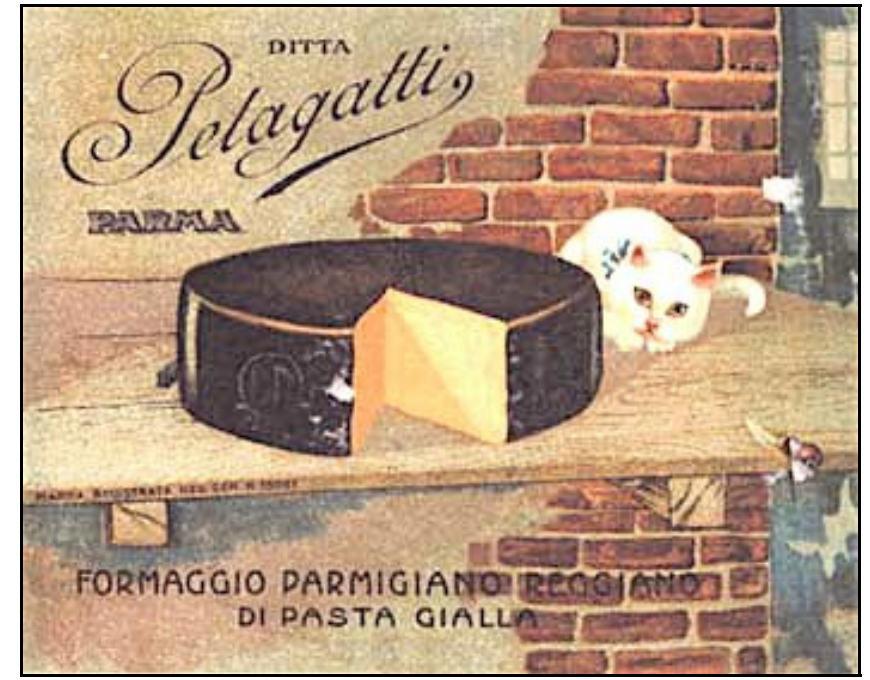

Figure 3. Advertisement poster, Parmigiano-Reggiano Pelagatti (1930).

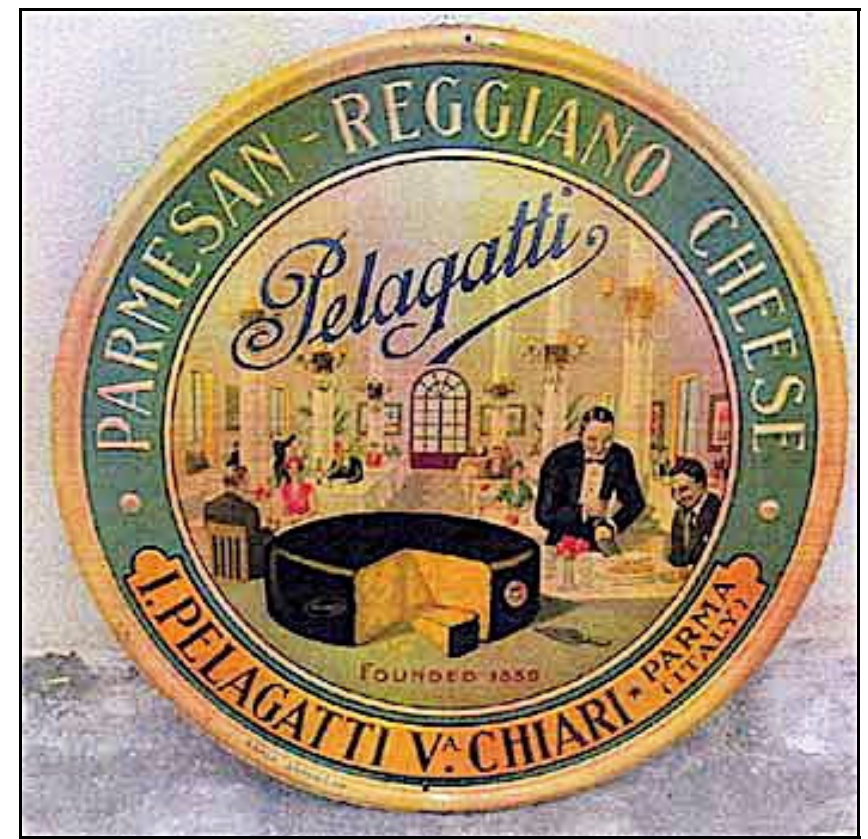

Figure 4. Metal plate, Parmigiano-Reggiano Pelagatti (1930).

Boccasile in his advertising underlines - with an almost maniacal insistence - the aspect of olfactory sense. This poster shows a pig-faced chef spellbound by a wheel of Parmigiano-Reggiano cheese. His eyes are shut to give absolute priority to smell, anticipating with his nose the savoury and spicy aromas that will go on to satisfy his taste buds too. This is metaphorically represented by closed, pouting lips appealing for the longed-awaited kiss of the cheese.

In the equally evocative poster by Mauzan, Parmigiano-Reggiano cheese is the focus of the olfactory senses of three men with huge noses. As evocative as the Boccasile poster, this scene is characterised by the greater "material" type of satisfaction. The faces of the three men look hot and excited by being near to the cheese fragrance. They are ready to eat it, but they first fulfil their olfactory need, which only heightens their desire to devour the cheese. 
Really, the beginning of a true communication strategy for the product took place in the early sixties, in parallel with the expansion of markets in the economic boom and taking advantage of the most important "new media" of that period: The television even though the advertising on newspapers remained essential for long time.

The 1963 advertising campaign (Figure 5) did explicit reference to tradition (for seven centuries, a great cheese). It is not yet a complete narrative code, but the gaps from the past are being filled. "Modernity" is being flanked by "tradition", for the first time indicating a syncretism between tradition and innovation. Overall, the poster is very elegant. The text has a single headline: Parmigiano-Reggiano: for seven centuries, a great cheese. There is no other text distracting attention from the statement. The elision of the final syllable of the Italian word, "gran" instead of "grande" is also significant. That word "gran" gives the sentence musicality and rhythm, and also alludes to "grana", the historical designation of Parmigiano, as well as the name of the product that was to become its chief competitor (Grana Padano).

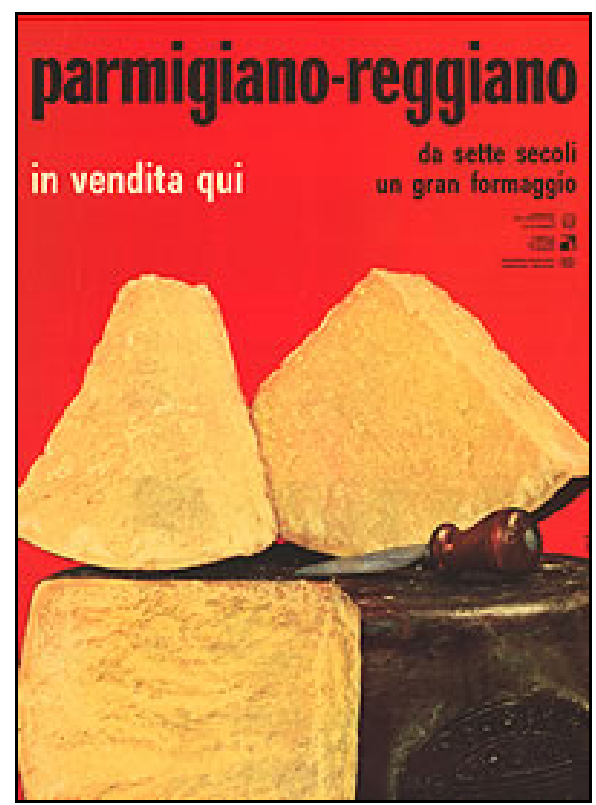

Figure 5. Advertisement poster by Consortium Parmigiano-Reggiano in 1963.

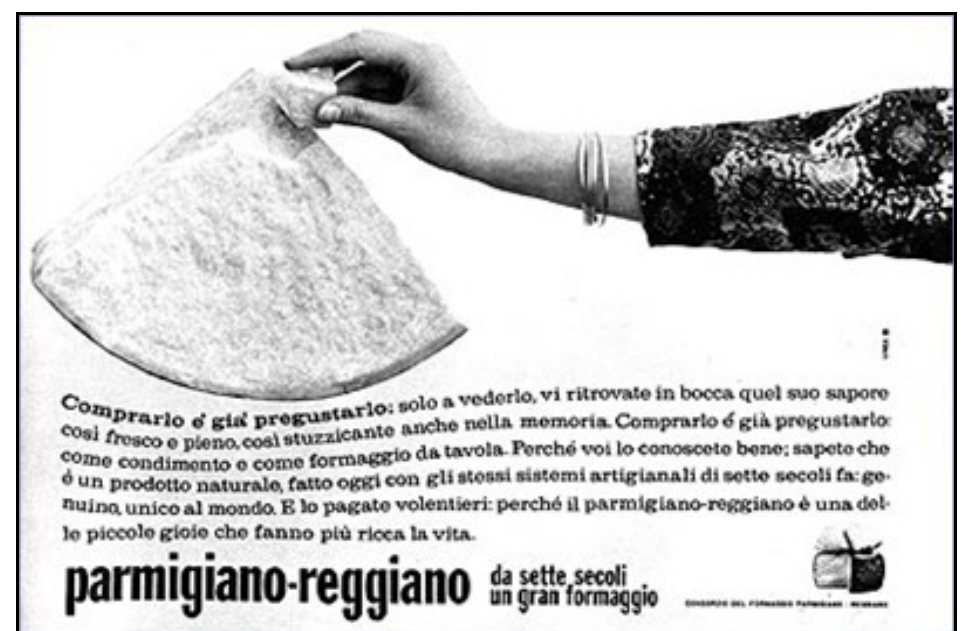

Figure 6. Newspaper advertisement by Consortium Parmigiano-Reggiano in 1964. 
The 1964 campaign was more complex (Figure 6). There are several elements to be underlined, starting with the use of an elegant black and white:

(1) The pleasure of buying is distinguished from tasting (buying it means tasting it). Before they even taste the cheese, consumers are delighted by the act of buying it;

(2) The use of memory recall (you taste that flavour [...] which also entices your memory). There is a clear reference to Proust in this statement. The consumer only has to nibble a piece of Parmigiano-Reggiano, for the flavour to trigger a memory of the past-the allusion to Proust's concept of "madeleine" obviously refers to that of "unintentional memory" (Benjamin, 1973) and on the power that taste has to evoke personal stories (Barolini, 1988), hinting at something or at somebody, just like a madeleine. It levers the "memory" of the consumer, who is attracted not only by the wonderful taste, but also by an association with a past event connected to positive sensations and emotions;

(3) The product "doubles up" (as a condiment or a table cheese). At the same time Parmigiano-Reggiano is both food and a dressing; especially for geographically distant consumers, this is a short "instruction manual";

(4) It is a familiar product (because you know it well). This statement suggests great familiarity; it proposes the image of a well-known product that resides in everyone's memory;

(5) The reference to naturalness (it is a natural product, made today using the same artisan systems as seven centuries ago). This declares not only that the product dates back seven centuries, but that the processing techniques have also remained unchanged;

(6) The underlining of uniqueness (unique in the world). Parmigiano-Reggiano is "unique" and "exceptional". There is also the intention to suggest that competitor cheeses may be good, but they are not unique.

(7) The price factor (you pay with pleasure). The product costs more than its competitors. Consumers are asked to pay a "premium price" because the product not only gratifies them, but also grants them social status.

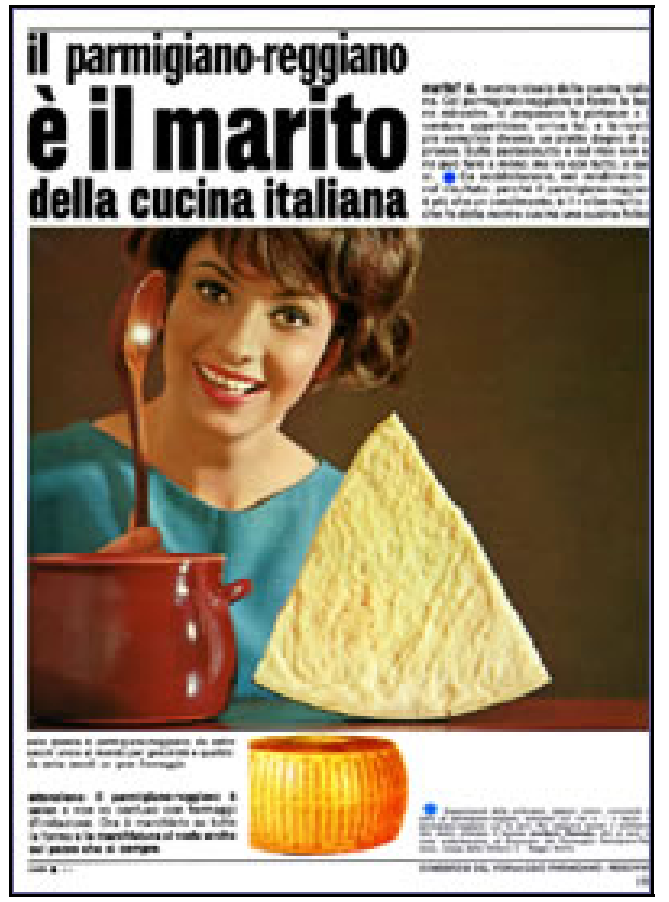

Figure 7. Newspaper advertisement by Consortium Parmigiano-Reggiano in 1966. 
Towards the middle of the 1960s, Italy was passing through economic boom peak. The headline of the poster used in 1966 is very clear and introduces some new elements (Figure 7). With its statement that "Parmigiano-Reggiano is the husband of Italian cuisine", the product becomes gendered and gets a precise identity associated with the social role of "husband". Playing on the evocative function rooted in traditional culture, the product thus takes on the important role that in those years was attributed to the "male head of household". This is a mimesis based on the metaphorical message that represents Parmigiano-Reggiano as the "husband" associated with a well-groomed female figure, the smiling housewife of an urban family getting to grips with the pan of meat sauce to dress the spaghetti or pasta. Among the children programs, for example, the advertising stands out as an outright summary of gender stereotypes. This advertising aims to get into consumers' head - exasperating them - the different roles that men and women have into society. In Italy all this was already very clear in the TV advertising communication of 1960s (Businaro, Santangelo, \& Ursini, 2006; Capecchi, 2006; Grossi \& Ruspini, 2007).

The text and image are closely linked, giving a "reassuring" message which revolves around traditional family values and thus underlines a reference to tradition, incarnated in the product being advertised. The Parmigiano/husband helps to ensure traditional equilibrium in defence of a social model which even then was gradually shattering — on changes occurring in Italian society during the 1960s (Crainz, 1996; 2003; Forgacs \& Gundle, 2007) and on changes in the consumption behaviors (Scarpellini, 2008).

Two years later there was a new step ahead (Figure 8). This is the table cheese for the man who deserves the best. This headline is closely linked to the graphics, which illustrates two central elements: the torso of a man sitting in front of a wheel of Parmigiano, on top of which there is a plate with a wedge of cheese and the special small knife to break off small chunks, and the arms of a woman - probably his wife-embracing him. What is unusual is that their faces are not shown and that they fill only a small part of the scene, and only certain details are shown.

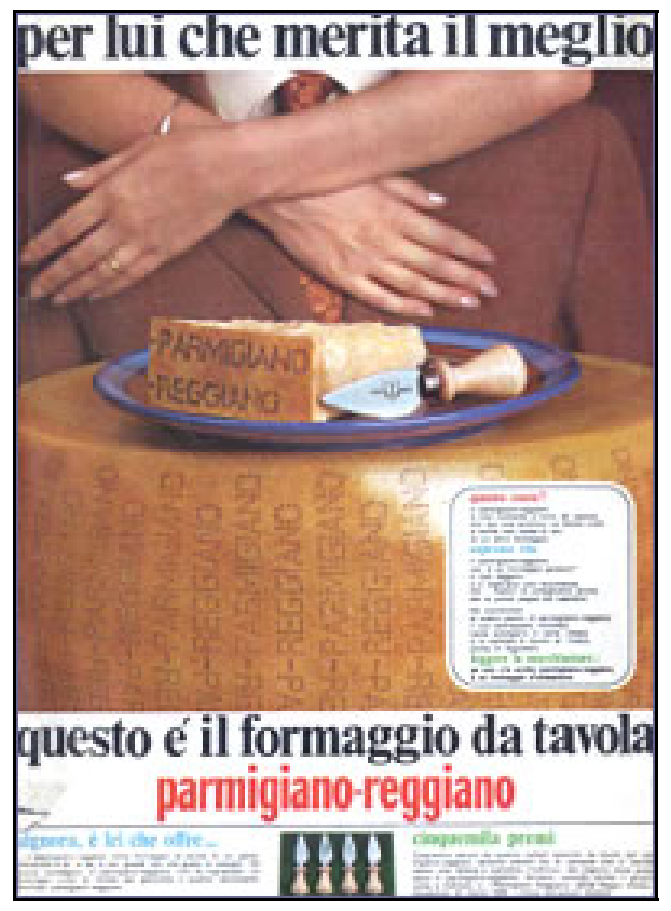

Figure 8. Newspaper advertisement by Consortium Parmigiano-Reggiano in 1968. 
But despite this incomplete nature, roles and identities are clear. That the man belongs to the urban middle class is testified by his jacket and tie. In fact, this is simply another way of representing the "husband" who appeared in the 1966 advert. By his side is his loving wife, with just enough details to identify her; the wedding ring shows her marital status, the bracelet on her right forearm is that of a woman from a wealthy family while her well-kept hands with their lacquered nails tell of someone who does not concern herself with housework.

There are numerous communicative innovations, but the cultural pattern is similar. The evocation of the family dimension is explicit, even though the communicative blueprint appears more "refined", leveraging the more "subtle" visual elements (the wedding ring, the tie, etc.). Moreover, the association Parmigiano/husband, which had been over explicit in the previous campaign, is now only hinted at in the opening lines ("for him"). The "closure" and pay-off of the ad are in fact quite interesting, and come across as somewhat subversive compared to the past. The product is no longer suggested as an accompaniment for the pasta course, but as food to be consumed as a main course. In this way, it was riding the crest of the wave of "modernity", which, especially for people no longer engaged in arduous manual labour, proposes lighter and meant lighter lunches, so that professional intellectual work could be done in the afternoon.

\section{Treasure Island: The Birth of Terroir}

In 1971 the first advertising campaign which unequivocally used the "virtue" of the terroir to promote the product appeared. It is a relevant change with the previous forms of communication, for many reasons. First, there is a need to confirm the cheese's "reputation" on markets, more and more distant from the production's region both in geographical and cultural terms, by closely linking Parmigiano-Reggiano's to its area of origin (while the demand of typical products follows standard patterns of consumption, the perception of the intrinsic value of typicality decreases as the distance between production and consumption increases) (Antonelli, 2000). A second factor that has likely directed marketing strategies is the Italian political agenda of that period: In 1970, the administrative subdivision of the country into regions, ruled by the 1948 constitution but never in force, was finally enforced. The whole issue was widely debated in the public arena in the previous decade covering not only the political side of the problem, but also encompassing features, such as the distinctive physical-geographical traits of the various regions of the country, whose oeno-gastronomical differences played a major role (Santarelli, 1960), on the role that administrative subdivisions play in creating a framework favourable to the rise of food typicality (Csergo, 2007).

In connection with this latter aspect, two more interrelated elements probably had an additional influence. On one hand, during the 1960 s the French AOC model was finally applied to Italian wines, through the Denominazione d'Origine Controllata (Protected Denomination of Origin) system. On the other hand, these decades witness a growing interest for "regional cuisine" that is united to the significant increase of domestic tourism boosted by mass motorisation: a fast and developing demand that marketing experts certainly did not ignore, for example, the first Denominazione d'Origine Controllata (DOC) was decreed in 1963 in favour of Marsala, shortly followed by several other wines (like Chianti) which had a long-standing connection with a specific area of production. Among the most prominent opinion-makers who guided the rediscovery of regional cuisine in Italy was the gastronomist, oenologist, and writer Luigi Veronelli; in 1966, he co-authored the first systematic book on this topic (Carnacina \& Veronelli, 1966), for the interplay between gastronomy and tourism (Csergo, 2007). 
The communicative framework is simple but sophisticated at the same time (Figure 9): The wheel of Parmigiano-Reggiano, already sliced to show the crystalline texture of the cheese's paste, lies on parchment which reproduces a map of the product's place of origin, embracing the provinces of Parma, Reggio Emilia, and Modena, and a part of those of Mantua and Bologna. These few elements enable to strengthen the advert's communicative power by transmitting the product's sense of "tradition" and "lengthy history" to the consumer. It is not simply a matter of promoting a cheese, but rather of celebrating a unique product in which the very best virtues of a wealthy and prosperous terroir are embedded. The sentence in the headline ("L'isola del Tesoro: la zona d'origine del Parmigiano-Reggiano"; "Treasure Island: Parmigiano-Reggiano's place of origin") can only be understood if compared to the image below:

(1) Note first and foremost the map: It is a roll of parchment on which the production area of Parmigiano-Reggiano is drawn (with the strokes and colours of ancient cadastral maps). The effect has a definite emotional impact: The Treasure Island — clearly read between the lines—is not a component of the advertising message, but represents an objective and unconfutable historical fact, deeply anchored in the memory;

(2) The contrast created by the muted, slightly uneven colour of the parchment and the equally uneven crystalline texture of the Parmigiano represents an evocative element of association intended to be kindled in the consumer's unconscious in the form of a chromatic assonance. The triangulation is simple. The map bears witness to the product's roots in a given terroir which has a "long history" behind it, made up of symbols and traditions, confirmed by the ancient parchment the Parmigiano is lying on. The product, destined to gratify the consumer's taste, is seen to have the same colours and indeed seems to be made of the same material as the parchment. Or to be more exact, in a mimetic process, it is the parchment that seems to be made of Parmigiano. At the end of this mental process, the circle closes and the goal of selling history as a "procreator of typicality" has been fulfilled. From this point of view, it is history (and its use) that builds on "tradition" rather than the product itself - the methodological reference is to Hobsbawm and Ranger (1983). Hobsbawm's approach is applied to typical food in works of Magagnoli (2005) and Grandi and Magagnoli (2013).

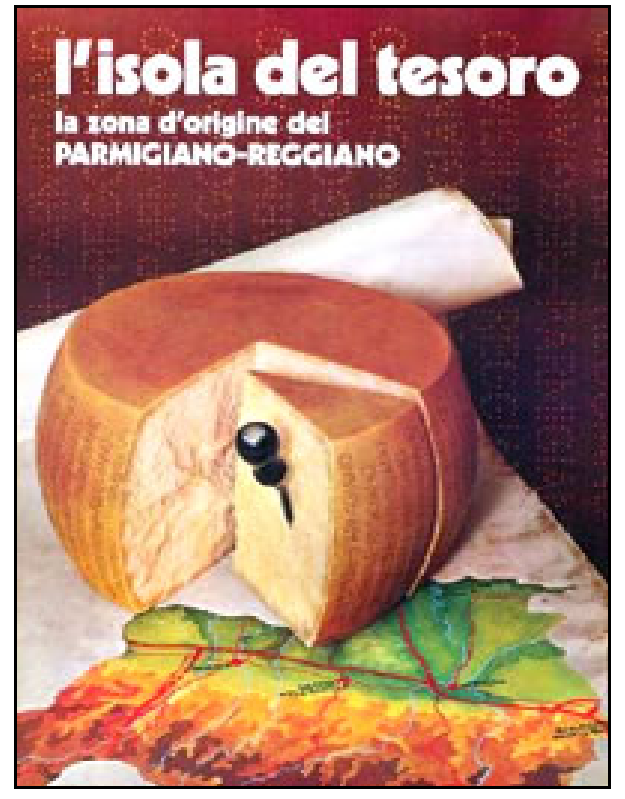

Figure 9. Newspaper advertisement by Consortium Parmigiano-Reggiano in 1971. 
At the ending of 1960s, the parallelism between Parmigiano-Reggiano cheese and treasure appeared in commercials on Carosello, the Italian state television main advertising "container". A series of cartoons - Briganti Mattacchioni ("The Joker Bandits"; some spots are available on-line)—shows four unlikely bandits in search of treasure to steal. The bandits use a variety of methods to reach their goal, from infiltrating a soldiers' camp to steal their wages, to trying to open the gates of a castle, and even trying to burgle an Egyptian pyramid and force open the secret treasure vault. However, the four bandits are the classic antiheroes of cartoons, and like the more famous Wile E. Coyote; they inevitably end up victims of their own escapades. Flattened, battered, or knocked out by unexpected explosions, the four jolly fellows quickly take to their heels, leaving room for the tail end of the commercial. This extols the real virtues of the "Treasure Island" of the Po Plain, which for many centuries has kept embedded the only real treasure worth knocking oneself out for Parmigiano-Reggiano.

The series was very effective, thanks above all to the charm of the music, the originality of the bandits' adventures and the overall brilliance of the communicative idea. The general narrative standard is powerful and explicit, appealing as it does to the ideals of history and tradition. Without rhetoric or artificiality, it maintains irony and a light touch and succeeds in conveying the tradition of the product through the characters' misadventures and jocularity.

\section{Parmigiano-Reggiano and Its Terroir}

The series was extremely successful, but showed no clear link with the place of origin or the long history of the product. The link however was clearly shown in the next series — starting in 1973 - set in the castles of the five provinces of the consortium production area. The series, symbolically, started in the castle of Torrechiara, in the province of Parma. The narrative structure is simple: A young couple is visiting by car the medieval castles that really exist in the manufacturing territory of Parmigiano-Reggiano cheese. They are received by a hypothetical lord of the manor (played by Arnoldo Foà, at that time well-known Italian theatrical actor) that entertains the couple with meticulous tales about the castle history. This series, in many ways, was very pedantic; probably unsuitable to attract or involve TV audiences in 1970s. This does not matter. The campaign aimed to show a strong link between product and place. Exactly like the parchment above. Even if this link was historically weak and somewhat artificial, it appeared here very realistic.

The link is realistic, even if Grana cheese had changed. By the 1970s, the raw material had changed and Friesian cattle were being milked instead of the traditional breed of Red Cows. Manufacturing and ripening techniques had also been modernised. The territory or area of production itself had changed. This did not matter. The typicality of the Parmigiano-Reggiano cheese was perceived as very high and this was the important thing for consumers. The Parmigiano-Reggiano typicality was able to hand down emotions to them. On an international scale, Parmigiano cheese came to be synonymous with quality.

The idea of typicality paved the way to market for the Parmigiano cheese producers, as well as a multitude of unlikely imitations; from the famous Parmesan from Wisconsin to the unique Parmesanito cheese spread from Argentina. In fact, these products are not even trying to copy the original, except in the evocative force of the name Parmesan.

But that is a whole different story which is represented by the narrow line that splits innovation, copy, and counterfeiting. 


\section{References}

Antonelli, G. (2000). Volumi di offerta e marketing. Il caso dei prodotti agro-alimentari tipici. Economia Agro-Alimentare, $2,56$. Barolini, H. (1988). Festa: Recipes and recollections of Italian holidays. San Diego: The University of Wisconsin Press.

Benjamin, W. (1973). Per un ritratto di Proust. Torino: Einaudi.

Boccaccio, G. (1527). Il Decamerone, Ottava giornata. Firenze: Heredi di Philippo di Giunta.

Bordo, M. D., Taylor, A. M., \& Williamson, J. G. (2003). Globalization in historical perspective. Chicago: The University of Chicago Press.

Businaro, C., Santangelo, S., \& Ursini, F. (2006). Parole rosa, parole azzurre. Bambine, bambini e pubblicità televisiva. Padova: Cleup.

Capecchi, S. (2006). Identità di genere e media. Roma: Carocci.

Carnacina, L., \& Veronelli, L. (1966). La cucina rustica regionale. Milano: Rizzoli.

Ceccarelli, G., Grandi, A., \& Magagnoli, S. (2013). Typicality in history. Tradition, innovation, and terroir. Bruxelles: Peter Lang.

Crainz, G. (1996). Storia del miracolo italiano. Culture, identità, trasformazioni fra anni Cinquanta e Sessanta. Roma: Donzelli.

Crainz, G. (2003). Il paese mancato. Dal miracolo economico agli anni ottanta. Roma: Donzelli.

Csergo, J. (2007). L'emergere delle cucine regionali: La Francia. In J. L. Flandrin and M. Montanari (Eds.), Storia dell'alimentazione (pp. 649-651). Laterza: Roma-Bari.

De Vries, J. (1994). The industrial revolution and the industrious revolution. The Journal of Economic History, 79(2), $249-270$.

Forgacs, D., \& Gundle, S. (2007). Cultura di massa e società italiana, 1936-1954. Bologna: Il Mulino.

Grandi, A., \& Magagnoli, S. (2013). Contrefaçon ou démocratisation du luxe? Les Avatars du Vinaigre Balsamique de Modène. In N. Sougy (Ed.), Luxes et internationalisation (XVI $I^{e} X I X^{e}$ siècles) (pp. 231-247). Neuchâtel: Editions Alphil-Pressses Universitaires Suisses.

Grossi, G., \& Ruspini, E. (2007). Ofelia e Parsifal. Modelli e differenze di genere nel mondo dei media. Milano: Raffaello Cortina Editore.

Guenzi, A., Massa, P., \& Moioli, A. (1998). Guilds, markets and work regulations in Italy, 16th-19th centuries. Aldershot: Ashgate.

Hancock, D. (2009). Oceans of wine: Madeira and the emergence of American trade and taste. New Haven: Yale University Press.

Hobsbawm, E. J., \& Ranger, T. (1983). The invention of tradition. Cambridge: Cambridge University Press.

Levati, S. (2002). Cibo sano, comodo a conservarsi e al trasporto, di squisito gusto: Il commercio del Parmigiano nello Stato di Milano tra Sette e Ottocento. In P. Battilani and G. Bigatti (Eds.), Oro bianco. Il settore lattiero-caseario in Val Padana tra Otto e Novecento. Lodi: Giona.

Maestro Martino de Rossi. (1467). Libro de arte coquinaria. Retrieved from http://www.uni-giessen.de/gloning/tx/martino2.htm

Magagnoli, S. (2005). L'invenzione "industriale" della tradizione: Il cartello dell'Aceto balsamico tradizionale di Modena. Food \& History, 3(1), 225-263.

Magagnoli, S. (2013). Made in Eataly: Identità e falsificazione. In C. M. Belfanti (Ed.), Contraffazione e cambiamento economico. Marche, imprese, consumatori. Milano: Egea.

Magagnoli, S. (2015a). Les produits typiques: Une construction urbaine? Réputation et terroir à partir d'une perspective italienne. In C. Marache and P. Meyzie (Eds.), Les produits de terroir. L'empreinte de la ville (pp. 31-48). Tours-Rennes: Presses Universitaires François-Rabelais de Tour et Presses Universitaires de Rennes.

Magagnoli, S. (2015b). La globalizzazione del gusto. Esposizioni universali e prodotti alimentari. Ricerche Storiche, 70(1-2), 41-49.

Santarelli, E. (1960). L'ente regione. L'idea regionalistica nei suoi termini storici, politici e costituzionali. Roma: Editori Riuniti.

Scarpellini, E. (2008). L'Italia dei consumi. Dalla Belle Époque al nuovo millennio. Roma-Bari: Laterza.

Smart Martin, A. (1993). Makers, buyers, and users: Consumerism as a material culture framework. Winterthur Portfolio, 53(2-3), 141-157.

Tanara, V. (1674). L'economia del cittadino in villa. Venezia: Stefano Curti.

Zannoni, M. (1999). Il Parmigiano-Reggiano nella storia. Parma: Silva Editore. 